\title{
Studies in man of phenytoin absorption and its implications
}

\author{
F. B. GIBBERD AND M. WEBLEY
}

From Westminster Hospital, London

SYNOPSIS The absorption of phenytoin was studied in man. It is concluded that phenytoin absorbed from the intestine is recirculated via the bile, so that blood levels do not accurately reflect absorption. Phenytoin is loosely bound to serum proteins and is found in red cells in concentrations similar to those in plasma. It is rapidly lost from the blood stream after intravenous administration, which is an important factor to be considered in the treatment of status epilepticus.

There is a considerable amount of information concerning the pharmacology of phenytoin (Woodbury et al., 1972), but there is no satisfactory explanation for the wide variation in the serum levels of patients receiving this drug. The variation could be due to many factors including absorption, metabolism, distribution, and excretion. As phenytoin is so commonly used in the treatment of epilepsy, an understanding of the factors leading to variations in the serum levels would assist in the management of patients. The rapid disappearance of phenytoin from the blood, which is known to occur, could be of considerable importance when considering emergency treatment of status epilepticus and cardiac arrhythmias.

In this paper oral and intravenous tolerance tests have been used to study phenytoin absorption. Protein binding, excretion in the bile, and distribution in red blood cells of phenytoin have also been studied.

\section{METHODS}

STUDIES OF ABSORPTION Oral and intravenous tolerance tests were performed. Patients fasted overnight and received no anticonvulsants for one week before the test. Oral tolerance tests were done on 12 patients. Each received $700 \mathrm{mg}$ phenytoin sodium in capsule form. Blood samples were collected halfhourly for three hours, one-hourly for a further five hours, and two further samples were collected at 10 and 12 hours.

Intravenous tolerance tests were performed on (Accepted 2 September 1974.) six patients, one of whom, after a cholecystectomy, had a T-tube in situ with free bile drainage. Phenytoin $125 \mathrm{mg}$ was given over a period of two minutes. Blood samples were collected into heparinized tubes at five minutes, 15 minutes, 30 minutes, and one hour, then one-hourly for a further seven hours and at 10 and 12 hours. Phenytoin was extracted and estimated by gas chromatography as described by MacGee (1970) with modifications to suit a Perkin Elmer F11 model. These were a block temperature of $350^{\circ} \mathrm{C}$ and a $\frac{1}{4}$ in. OD glass column packed with $2 \frac{1}{2} \%$ OV17 silicone on $97 \frac{1}{2} \%$ chromosorb $80-100$ mesh column at $215^{\circ} \mathrm{C}$.

DISTRIBUTION OF PHENYTOIN Distribution of phenytoin between plasma and red cells was estimated: phenytoin in $25 \mathrm{mmol} \mathrm{NaHCO}_{3}$ was added to blood. This was centrifuged at $3000 \mathrm{rpm}$ for four minutes. Phenytoin was then extracted from the cellular and plasma fractions. A double extraction was performed on the cellular fraction to remove traces of haemoglobin. Phenytoin was extracted and estimated by spectrophotometry as described by Svensmark and Kristensen (1963).

PROTEIN BINDING OF PHENYTOIN Protein binding was measured by a dialysis technique. Dialysis sacks (Sigma Chemical Co.) were suspended in $12 \%$ dextrose.

Ten millilitres of a solution containing citric acid/phosphate buffer $(0.915 \mathrm{ml} 0.1 \mathrm{M}$-citric acid: $9.085 \mathrm{ml} 0.2 \mathrm{M}$-disodium phosphate) $\mathrm{pH} \mathrm{7.4,50 \mu \textrm {g }}$ phenytoin and known dilutions of plasma with a protein concentration of $70 \mathrm{~g} / \mathrm{l}$ were made up.

Five millilitres of the solution were placed in the dialysis sack, weighed, immersed in dextrose, and 


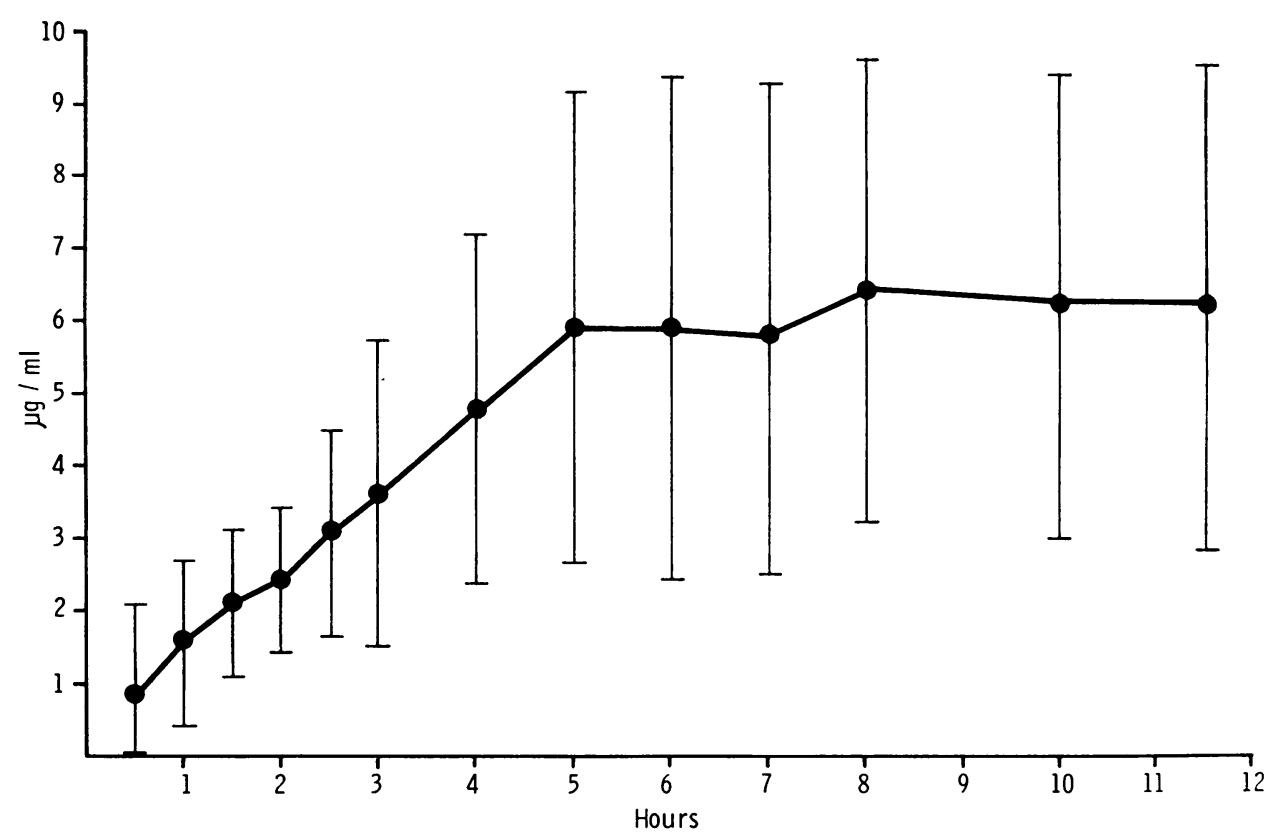

FIG. 1 Oral phenytoin tolerance tests. Twelve patients were given $700 \mathrm{mg}$ phenytoin orally. The mean values of the plasma concentration and two standard deviations are plotted against time.

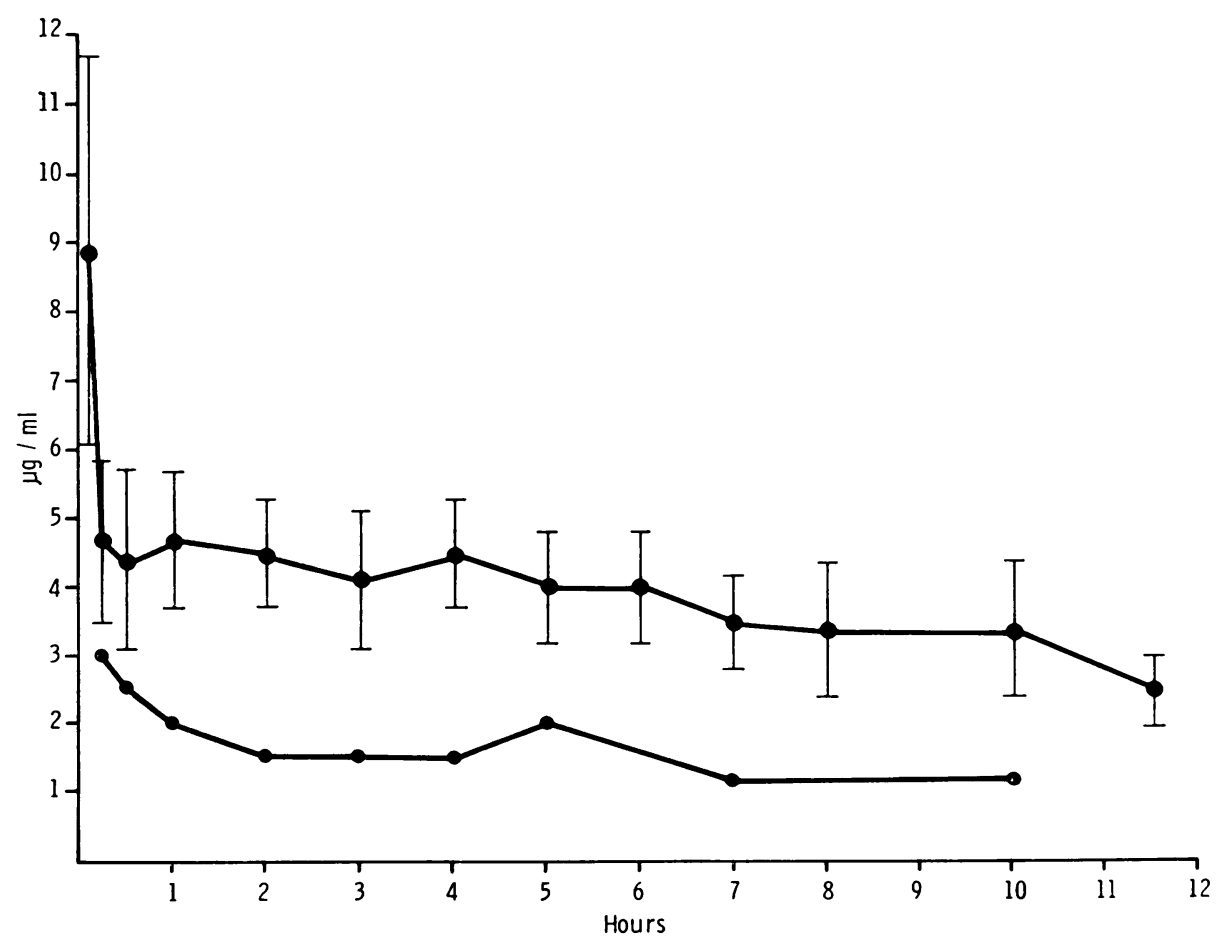

FIG. 2 Intravenous phenytoin tolerance tests. The upper curve is the result of giving five patients $125 \mathrm{mg}$ phenytoin intravenously. The mean values of the plasma concentrations are plotted against time. The lower curve is the result in one further patient with a bile tube in situ. 
then placed in a water bath at $30^{\circ} \mathrm{C}$ for 20 hours. The sack was then re-weighed.

Phenytoin levels in both the bathing solution and the remaining plasma in the sack were estimated using spectrophotometry (Svensmark and Kristensen, 1963). As the amount of water passing through the membrane varied with differing plasma concentrations, the weighing data were used to make the corrections. Varying phenytoin concentrations were used and tests were done in duplicate.

EXTRACTION OF PHENYTOIN IN BILE Bile was obtained from patients on phenytoin who had T-tubes in situ after surgery for biliary conditions which had not altered liver function. Quantitative estimations were not reliable as interference from bile pigments occurred. Qualitative tests were done.

Twenty millilitres of bile and $5 \mathrm{~g}$ Fuller's earth were centrifuged. Phenytoin was extracted from $10 \mathrm{ml}$ of this sample, again using the method described by Svensmark and Kristensen (1963). The final solution was acidified to $\mathrm{pH}$ 6.7, extracted into chloroform and dried.

The remaining material was dissolved in $0.5 \mathrm{ml}$ ethanol and spotted on Whatman No. 1 paper previously soaked in $10 \%$ trisodium ortho-phosphate solution and then dried.

Chromatography was then done using isoamyl alcohol-methanol-ammonium hydroxide 5:1:1 v/v. After drying, phenytoin appeared as a black spot under ultraviolet light. The relative loss of intensity depended on the concentration.

\section{RESULTS}

Figure 1 shows the results of oral tolerance tests from 12 patients whose details are shown in Table 1. The serum level of phenytoin rises slowly to reach a peak at about eight hours which is then maintained to 12 hours. These findings are similar to those of Dill et al. (1956) who found the plasma half life of phenytoin to be 18-24 hours. All patients had a tolerance curve of a similar type but some patients had no detectable phenytoin in their blood until two hours after administration. Serum levels showed a very wide range. For example, at two and a half hours when the mean phenytoin level was $3.1 \mu \mathrm{g} / \mathrm{ml}$, the standard deviation was 1.4 , and at eight hours with the mean at $6.4 \mu \mathrm{g} / \mathrm{ml}$, the standard deviation was 3.2. There was no evidence of hepatic dysfunction as judged by serum transaminases, alkaline phosphatase, and plasma proteins. Bromsulphthalein retention
TABLE 1

DIAGNOSES OF PATIENTS WHO HAD ORAL PHENYTOIN TOLERANCE TESTS

\begin{tabular}{|c|c|c|c|}
\hline Patient & $\begin{array}{l}\text { Age } \\
\text { (a) }\end{array}$ & Diagnosis & $\begin{array}{c}\text { Previous } \\
\text { anticonvulsants }\end{array}$ \\
\hline 1 & 22 & Epilepsy & Phenobarbitone \\
\hline 2 & 69 & Pernicious anaemia & Nil \\
\hline 3 & 20 & Epilepsy & Nil \\
\hline 4 & 51 & $\begin{array}{l}\text { Subarachnoid haemorrhage, } \\
\text { epilepsy }\end{array}$ & $\begin{array}{l}\text { Phenytoin } \\
\text { Phenobarbitone }\end{array}$ \\
\hline 5 & 55 & $\begin{array}{l}\text { Partial gastrectomy, } \\
\text { B12 deficiency }\end{array}$ & Nil \\
\hline 6 & 35 & Epilepsy & Phenobarbitone \\
\hline 7 & 49 & $\begin{array}{l}\text { Epilepsy, vagotomy, and } \\
\text { pyloroplasty }\end{array}$ & Phenobarbitone \\
\hline 8 & 51 & $\begin{array}{l}\text { D.U. vagotomy, } \\
\text { cholecystectomy }\end{array}$ & Nil \\
\hline 9 & 23 & Crohn's, colectomy & Nil \\
\hline 10 & 49 & Myxoedema & Nil \\
\hline 11 & 67 & Dementia, B12 deficiency & Nil \\
\hline 12 & 57 & Epilepsy & Nil \\
\hline
\end{tabular}

TABLE 2

DIAGNOSES OF PATIENTS WHO HAD INTRAVENOUS PHENYTOIN TOLERANCE TESTS

\begin{tabular}{|c|c|c|c|}
\hline Patient & $\begin{array}{l}\text { Age } \\
\text { (a) }\end{array}$ & Diagnosis & $\begin{array}{c}\text { Previous } \\
\text { anticonvulsants }\end{array}$ \\
\hline 1 & 30 & Convulsions & Nil \\
\hline 2 & 21 & $\begin{array}{l}\text { Convulsions, } \\
\text { Anorexia nervosa }\end{array}$ & Nil \\
\hline 3 & 50 & Pernicious anaemia & Nil \\
\hline 4 & 72 & Pernicious anaemia & Nil \\
\hline 5 & 54 & Epilepsy & $\begin{array}{l}\text { Phenytoin } \\
\text { Phenobarbitone }\end{array}$ \\
\hline 6 & 51 & $\begin{array}{c}\text { Cholecystectomy, } \\
\text { T-tube in situ }\end{array}$ & Nil \\
\hline
\end{tabular}

tests were not done. Prior treatment with phenytoin did not affect the rate of absorption.

Figure 2 shows the results of intravenous tolerance tests in six patients, detailed in Table 2 , and, in addition, the tolerance curve of a patient with a biliary T-tube in situ. There is a much narrower range of values (lower standard deviation) than there is in the oral tests. For example, at three hours when the mean phenytoin level was $4.1 \mu \mathrm{g} / \mathrm{ml}$ the standard deviation was 1.0 and at eight hours the mean was $3.4 \mu \mathrm{g} /$ $\mathrm{ml}$ and the standard deviation was 1.0. The tolerance curve of the patient with a biliary T-tube in situ was significantly below the normal curve at all stages. These intravenous studies show a rapid loss of phenytoin within the first 
TABLE 3

PHENYTOIN DISTRIBUTION BETWEEN RED BLOOD CELLS AND PLASMA

\begin{tabular}{cccc}
\hline \multicolumn{4}{c}{$500 \mu g$ phenytoin added to } \\
$10 \mathrm{ml}$ blood
\end{tabular}

15 minutes followed by a slowly progressive fall in the serum levels.

The distribution of phenytoin between red blood cells and plasma is shown in Table 3 . On average $10 \mathrm{ml}$ of blood yielded $4.4 \mathrm{ml}$ of cells and $5.6 \mathrm{ml}$ of plasma. Phenytoin is equally distributed between the two fractions. The period allowed for equilibration did not significantly alter the results.

The distribution of phenytoin was calculated from the results of the intravenous tolerance tests and a knowledge of the weights of the patients, which ranged from $56-85 \mathrm{~kg}$ (average $67 \mathrm{~kg}$ ). A total blood volume of 6 litres was assumed. At 15 minutes the mean plasma phenytoin was $4.7 \mu \mathrm{g} / \mathrm{ml}$. Thus only about $15 \mathrm{mg}$ (about half the total of blood phenytoin) of the administered $125 \mathrm{mg}$ dose are present in the plasma at this time. As the distribution betwee plasma and red cells is equal at this time abouf $95 \mathrm{mg}$ or $76 \%$ of phenytoin has left the bloo stream.

PROTEIN BINDING Results of dialysis exper ments (Table 4) show the calculated concentra? tion of bound phenytoin and dialysable (unbound) phenytoin for a range of serum protein concentrations. At a serum protein cons centration of $70 \mathrm{~g} / 1$ it may be calculated tha $99 \%$ of the phenytoin becomes protein bound By decreasing the amount of plasma in the dialy sis sack and thus relatively increasing the cones centration of phenytoin, the unbound concentration of phenytoin increases proportionately more than the bound level.

PHENYTOIN EXCRETION IN BILE Three patient who had T-tubes in situ after cholecystectom 9 were studied. Phenytoin could be detected wi fho $^{\omega}$ in 15 minutes of giving oral phenytoin. Quañtto tative tests were not possible owing to in ference from bile pigments and salts. maximum excretion did, however, seem tro occur between 15 and 30 minutes.

\section{DISCUSSION}

After oral administration of phenytoin, plasma levels show a very wide variation betwee individual patients, although all patients show tolerance curve of a similar type. No obvioug

TABLE 4

DIALYSIS EXPERIMENTS

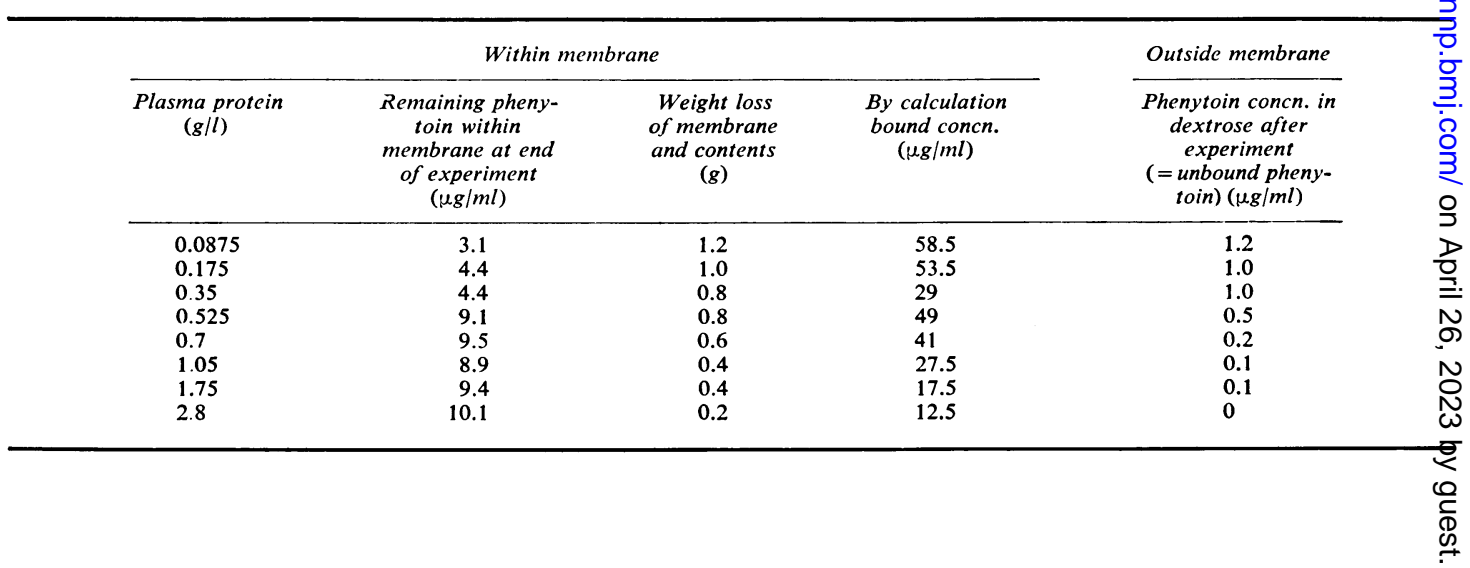


reason was found to account for the wide normal variation.

Previous workers (Arnold et al., 1970) have shown that altering the gastric $\mathrm{pH}$ by administration of sodium bicarbonate does not alter the rate of absorption. This agrees with our findings in five patients with proven achlorhydria. In these patients the same variability of plasma levels and shape of tolerance curve was obtained.

After intravenous administration a much narrower range of plasma levels occurs, suggesting that there is a wide variation in the rate of absorption from the gastrointestinal tract in different patients. The intravenous tolerance test in the patient with a biliary T-tube in situ falls well below the lower standard deviations of other patients, which shows that a high percentage of phenytoin is rapidly excreted into the bile. An oral tolerance test on this patient subsequently showed normal absorption and it is unlikely that post-operative disturbances in hepatic function could be responsible in this patient as delayed metabolism and conjugation with consequently higher plasma levels would have been expected. In this patient phenytoin was measured in the bile in significant concentration at 15 minutes. Biliary excretion of phenytoin may be a factor in prolonging absorption and might also explain the variation in plasma levels obtained after a single oral dose. It would also explain the slow fall in plasma levels after the first 15 minutes, some of the phenytoin having presumably been recirculated and reabsorbed from the gastrointestinal tract.

Previously, a biphasic tolerance curve in both intravenous and oral tests has been reported using a spectrophotometric method of estimation (Handley, 1970). Using gas chromatography we were unable to substantiate these findings.

It has been shown (Nakamura et al., 1967) that after the ingestion of a single dose of phenytoin in rats, the level in the liver remains high over a period of 48 hours. Glazko et al. (1969) studied phenytoin distribution in man and showed that the half life was 15.4 hours. They considered that the rapid uptake of phenytoin by the liver might account for its slow dispersal. From their results, it is obvious that there is a rapid loss of phenytoin from the blood between the fifth and twentieth minute. This means that experiments on the rate of absorption and the time to reach a maximum blood level do not necessarily reflect the rate of absorption from the gut. This variable absorption has been cited as a possible cause for wide variation in plasma levels but previous studies have shown that a change from oral to intramuscular phenytoin does not alter serum levels (Cantu et al., 1968). If phenytoin is given intramuscularly blood levels rise more slowly than when given orally (Dam and Olesen, 1966).

Phenytoin is bound to alpha globulin (Lightfoot and Christian, 1966) and is known to compete with thyroxine for binding sites. Protein binding has been studied in various ways. Loeser (1961), using a dialysis technique, found about $77 \%$ of phenytoin in serum to be protein bound, the percentage being proportional to the serum albumin concentration.

Other workers (Borgå et al., 1969; Lunde et al., 1970; Lund et al., 1971), using ultrafiltration methods, have shown over $90 \%$ to be bound. We found $99 \%$ to be protein bound. It seems likely that the percentage of phenytoin estimated as bound depends on the method used, but all results show that serum proteins are capable of binding larger amounts of phenytoin than occur in clinical practice. This binding must be loose for rapid dispersal to occur.

Protein binding may therefore account for some of the anomalies that have been observed in the relationship between the therapeutic effect, the blood level and the dosage of phenytoin. Patients with abnormal levels of serum proteins might react differently to phenytoin, although this is unlikely to be a factor in the majority of patients with uncomplicated epilepsy.

It has been shown from animal experiments (Dill et al., 1956) that, after oral administration of phenytoin, tissue levels correlate with blood levels but are two to three times greater.

The clinical significance of the rapid loss of phenytoin from the blood and equilibration throughout the body tissues is that during the treatment of both status epilepticus and cardiac. arrhythmias, where a rapid response is desirable, therapeutic levels will not be reached unless. either a very large loading dose or frequently repeated injections are given. 
We would like to thank the British Epilepsy Association for financial support towards this research.

\section{REFERENCES}

Arnold, K., Gerber, N., and Levy, G. (1970). Absorption and dissolution studies on sodium diphenylhydantoin capsules. Canadian Journal of Pharmaceutical Sciences, 5, 89-92.

Borgå, O., Azarnoff, D. L., Forshell, G. D., and Sjöqvist, F. (1969). Plasma protein binding of tricyclic antidepressants in man. Biochemical Pharmacology, 18, 2135-2143.

Cantu, R. C., Schwab, R. S., and Timberlake, W. H. (1968). Comparison of blood levels with oral and intramuscular diphenylhydantoin. Neurology (Minneap.), 18, 782-784.

Dam, M., and Olesen, V. (1966). Intramuscular administration of phenytoin. Neurology (Minneap.), 16, 288-292.

Dill, W. A., Kazenko, A., Wolf, L. M., and Glazko, A. J. (1956). Studies on 5, 5'-diphenylhydantoin (Dilantin) in animals and man. Journal of Pharmacology and Experimental Therapeutics, 118, 270-279.

Glazko, A. J., Chang, T., Baukema, J., Dill, W. A., Goulet, J. R., and Buchanan, R. A. (1969). Metabolic disposition of diphenylhydantoin in normal human subjects following intravenous administration. Clinical Pharmacology and Therapeutics, 10, 498-504.

Handley, A. J. (1970). Phenytoin tolerance tests. British Medical Journal, 3, 203-204.
Lightfoot, R. W., Jr, and Christian, C. L. (1966). Serum protein binding of thyroxine and diphenylhydantoin. Journal of Clincial Endocrinology, 26, 305-308.

Loeser, E. W., Jr, (1961). Studies on the metabolism of diphenylhydantoin (Dilantin). Neurology (Minneap.), 11, 424-429.

Lund, L., Lunde, P. K. M., Rane, A., Borgå, O., and Sjöqvist, F. (1971). Plasma protein binding, plasma concentrations, and effects of diphenylhydantoin in man. $\supset$ Annals of the New York Academy of Sciences, 179, 723-728.0.

Lunde, P. K. M., Rane, A., Yaffe, S. J., Lund, L., and Sjöqvist, F. (1970). Plasma protein binding of diphenyl-: hydantoin in man. Interaction with other drugs and the effect of temperature and plasma dilution. Clinical Pharma-cology and Therapeutics, 11, 846-855.

MacGee, J. (1970). Rapid determination of diphenylhydan-음 toin in blood plasma by gas-liquid chromatography. Analytical Chemistry, 42, 421-422.

Nakamura, K., Masuda, Y., and Nakatsuji, K. (1967).르 Tissue distribution and metabolic fate of 3-ethoxycar-sొ bonyl-5, 5-diphenylhydantoin (P-6127) and 5, 5-diphenyl-hydantoin in rats. Archives of International Pharmacology, 0 $165,103-111$.

Svensmark, O., and Kristensen, P. (1963). Determination of diphenylhydantoin and phenobarbital in small amounts of serum. Journal of Laboratory and Clinical Medicine, 61, 501-507.

Woodbury, D. M., Penry, J. K., and Schmidt, R. P. (1972). Antiepileptic Drugs. Raven Press: New York. 